V. Bilohur ${ }^{1}$, Dr. Sc. (Phil.), Prof., orcid.org/0000-0001-9041-7050, O. Kravchenko², Cand. Sc. (Phil.), Assoc. Prof., orcid.org/0000-0002-8736-8128,

T. Lishchuk-Torchynska ${ }^{3}$, Cand. Sc. (Phil.), Assoc. Prof., orcid.org/0000-0002-0118-5321,

N. Yukhymenko², Cand. Sc. (Phil.), Assoc. Prof., orcid.org/0000-0001-7739-9716
1 - Melitopol State Pedagogical University named after Bohdan Khmelnytsky, Melitopol, Ukraine

2 - Pereiaslav-Khmelnytskyi Hryhorii Skovoroda State Pedagogical University, Pereiaslav, Ukraine, e-mail: Natale_ux@ ukr.net

3 - Lesya Ukrainka Eastern European National University, Lutsk, Ukraine

\title{
GENERIC AND PROFESSIONAL MANAGERIAL SKILLS: CHANGING NATURE, THINKING AND ROLES
}

Purpose. To study changes in the nature, thinking and roles of generic and professional skills in various organizational cultures.

Methodology. In the study, the authors used the method of comparative analysis, which allowed us to contrast and compare existing organizational cultures. The methods of analysis and synthesis were used, which made it possible to identify and consider the use of managerial skills in each of the organizational culture. Methods of induction and deduction, as well as mental modeling, made it possible to establish changes in the nature of skills, way of thinking and the roles of generic and professional skills in various organizational cultures.

Findings. The authors examined the nature, thinking and roles of generic and professional managerial skills in Weberian bureaucracy, Mintzberg's adhocracy, and self-managing organizations. It is proved that in order to achieve the agreement in interpreting the nature of generic and professional skills, it is necessary to change the idea of a university as a public institution. At least, the idea of self-organizing universities has to be accepted.

Originality. It is proved that the embodiment of the idea of self-organizing universities is a prerequisite for the creation of autonomous organizations, whose self-realization efficiency is recognized as the most effective in comparison with Weberian bureaucracy and Mintzberg's adhocracy.

Practical value. The results of the study expand the understanding of the nature, thinking and roles of generic and professional managerial skills in various organizational cultures. The study demonstrates the efficiency of self-organizing universities and their significance in revealing the nature of man, in particular, the nature of managerial skills.

Keywords: managerial skills, organizations' culture, bureaucracy, adhocracy, self-managing organizations, management, generic skills, professional skills, self-organizing University

Introduction. In recent decades, innovations and innovative approaches have been the subject of close scrutiny. Such close attention to innovations is explained by the fact that they are one of the driving factors for the successful renewal of organizations, organization management and organizational culture. At the same time, both innovations themselves and organizational culture are created by people and their relationships.

The subject of the authors' research is one of the aspects of human relations, which has an important influence on both the creation and promotion of innovations, and on the development of the organizational culture. In the article, the authors explore changes in understanding generic (academic, transferrable) and professional skills of managers. The authors will successively solve three problems:

1. Considering the changes in understanding the nature of generic and professional skills of managers in various organizational cultures.

2. The relationship between understanding the nature of skills and thinking of managers with a change in understanding of the idea of a university as a social institution.

3. Considering the difference in understanding the nature, thinking and role of generic and professional managerial skills in the traditional understanding of the idea of a university and the idea of a self-organizing university.

Results. Three main organizational cultures are distinguished in modern science: Weberian bureaucracy, Mintzberg's adhocracy and self-managing organization [1]. Each of the three organizations has its own history of development and, accordingly, its own history of attitude to nature, thinking and the role of generic and professional skills of managers. We briefly consider the history of the development of each organi-

(C) Bilohur V., Kravchenko O., Lishchuk-Torchynska T., Yukhymenko N., 2020 zation, as well as the peculiarities of understanding the nature of managerial skills in these organizations.

Bureaucracy was the first scientific understanding of an organization and organization management. M. Weber proposed bureaucracy as the perception of an organization in the early $20^{\text {th }}$ century. In the book Max Weber's Vision for Bureaucracy, the authors argue that, as the basis of his views on bureaucracy, Weber used the ideas of the highly effective military bureaucracy of the General Staff of Prussia at that time, which were developed by Clausewitz and Helmuth von Moltke on the eve of the First World War [2]. Therefore, the Weberian bureaucracy model as an organizational paradigm was used as a basis not only in the construction of economic and social theories, but also the theories of war and peace.

Bureaucracy as an approach to the study of organizational culture is based on six principles: 1) legally fixed and orderly rules; 2) a clearly defined hierarchical system of authorities; 3 ) management based on a written document flow; 4) the need for training specialists; 5) the presence of the concept of "workplace", which requires the full workability of an official; and 6) management according to the established rules, which can be essentially studied [1].

In bureaucracy as an organizational paradigm, the nature of the generic and professional skills of managers is different. Generic skills are basic and are formed in the academic environment of universities [3]. They were considered as a special culture, the "university spirit", which determined the whole future life of man. This view of academic education was explained by the ideas of Wilhelm von Humboldt relevant to those of Weber. Humboldt attached particular importance to universities and the universal worldview that universities formed in the younger generation. For Weber, as well as for Humboldt, "university spirit" is the polymatheia and breadth of coverage of any problems that distinguished a university graduate in any profession and in any field of activity [4]. It 
was the university that formed intellectuals, the social elite, a special social stratum capable of driving the development of society and all areas of activity.

Accordingly, managerial skills, which were formed at a university as a social institution, were paramount. Due to the fact that they were laid at the first stages of training managers, they formed a special, managerial perception of the world that distinguished managers from other professions. They formed the ruling class or nomenclature. A university formed a universal base for the general managerial skills that could be used in production, public and military service. These skills were fundamental and universal for any bureaucratic organization. They were formed in the academic environment and remained relevant until the end of human life.

Weber considered professional skills to be secondary ones that could only be formed on the basis of generic skills. Professional skills were formed in the course of managerial experience, as well as further improvement of managerial qualifications. Professional skills were necessary and individual. Their formation presupposed special methodologies, which at most were not related to training. However, this was already a secondary product, which only enriched the nature of the initial and defining generic skills.

In the bureaucratic organizational culture, it was believed that the generic skills acquired in the academic environment were enough for a successful managerial career. Professional skills only adapted generic skills to a specific management model. Their nature and role in human life were seen as secondary.

The second approach to understanding of an organization is the paradigm of adhocracy, which is often contrasted with the paradigm of bureaucracy. The term "adhocracy" was coined by W. Bennis in 1968. The scientific paradigm of adhocracy was formulated by H. Mintzberg at the end of the twentieth century. Adhocracy is an organizational structure in which highly qualified experts work in multidisciplinary teams that produce unique results. Adhocracy provides for the absence of a formal structure, hierarchy and subordination. This is a decentralized organization, the coordination of which is achieved to a large extent through mutual adaptation. Mintzberg considered the organizations of consulting firms, advertising agencies, film companies, space agencies, etc. to be the examples of adhocracy. In adhocracy, the hierarchy of management is relative. There is no direct submission, and the integration of functional units or specialized multidisciplinary teams is carried out by the matrix organization. The fact of the presence of the matrix organization in itself is an integrating force, which essentially provides for the integrity of the decentralized structure of an organization and its management features.

The complex and dynamic culture of adhocracy provides a new understanding of the nature of managerial skills, as well as a new relationship between the generic and professional skills of a manager. Mintzberg preferred postgraduate programs that train practicing managers. He believed that professional skills could not be acquired in an academic setting. They are acquired only in a special environment in which training is carried out by practitioners based on personal experience and the results achieved in managing large organizations. Trainees should also be practitioners with only less managerial experience and more modest results achieved. The available managerial experience helped students to fully absorb the knowledge built on the experience of teachers-managers, as well as improve the effectiveness of their behavior in management models and even the management models themselves.

Mintzberg noted that students and graduates of even the most prestigious management schools, who had minimal experience in real management, were not prepared for the manager's jobs. The generic skills that the academic environment forms are too abstract and divorced from reality. Moreover, students, due to their too young age, lack of interest and expe- rience, are not able to perceive the scale of knowledge and the key importance of the experience of teachers-practitioners. For them, all the information provided by teachers seems to be general and superficial knowledge. This knowledge does not significantly affect the formation of professional qualities.

That is why Mintzberg contrasted academic and professional education. The former form generic skills that are not adapted to real environments and management models. Generic skills have no real significance in managing organizations. Professional education is able to influence only managers with work experience. It is effective only in case of the manager's conscious need for professional growth in the chosen profession.

Mintzberg argued that only in professional or postgraduate education, when the students are managers with work experience, the knowledge of teachers-practitioners turns from general "academic" information into effective managerial professional skills. In postgraduate education, the experience and knowledge of a reputable manager-practitioner have a direct impact on the thinking of management students and open up the possibility for them to improve not only their managerial skills, but also management models. Therefore, only postgraduate education has a key regulatory function [5]. Namely, only postgraduate education is able to form the professional skills that are necessary for successful self-actualization and professional career.

The third approach to understanding of an organization is the culture of self-managing organizations. The main feature of self-managing organizations is the radical decentralization of power. In practice, this means a virtually complete absence of management hierarchy in an organization.

Studying the history of the theory of self-managing organizations, M. Lee and A. Edmondson identified three key stages: 1) creating theories of post-bureaucratic organizations, 2) creating theories of humanistic management, 3 ) creating the theory of organizational democracy [6]. With each new stage, a person became conscious that the management hierarchy, which for thousands of years had been considered basic and the only possible, in fact, was not the most successful in terms of efficiency. Organizations, in which management is decentralized and transferred to the performers themselves, appear to be the most effective. Such organizations were called self-managing organizations.

Self-managing organizations are defined by three main characteristics:

1. Decentralization of power is radical and systemic. The hierarchical reporting relationship between the manager and the subordinate is (almost) completely eliminated, and employees have every right to make key decisions regarding their work.

2. Decentralization of power occurs throughout the organization. Top management makes only a few key decisions.

3. Decentralization of power is formal and systemic. Informally delegated powers can be revoked at any time, which is a deterrent to subordinates.

In self-managing organizations, decentralization of power is codified in clearly defined organizational principles that institutionalize the way of self-management, which actually prohibits managers from exercising certain forms of power [1]. At the moment, a self-managing organization is considered as the most emancipated organization, which has the highest efficiency of internal potentials self-actualization.

In self-managing organizations, we again observe a change in understanding the nature, thinking and the roles of generic and professional skills. The first place is given to academic training, which maximally reveals the inner potentials of a person referred to the term "arete" in ancient Greece [7]. However, it involves the formation of neither a specific set of generic skills nor a set of managerial skills. For self-managing organizations, the generic skills and potential of a manager are not decisive. The term "arete" provides for the disclosure of a 
set of basic qualities that are naturally inherent in man. Correspondence of internal qualities to external manifestations is the reason for the maximum self-actualization of a person in a self-managing organization. The same reason is determining for:

a) involving a person in a specific self-managing organization that meets the disclosed qualities of "arete": tion

b) ensuring the effective work of a person in this organiza-

c) the transfer of internal qualities ("arete") into professional skills, as well as their continuous perfection.

In fact, a person carries out self-actualization in an environment that not only corresponds to their inner nature, but also stimulates continuous perfection and self-development.

As soon as the environment ceases to correspond to the internal nature of man and begins to limit the manifestations of their inner essence, a person goes into another self-managing organization. That is, a self-managing organization in itself creates and regulates only certain favorable conditions for selfactualization. While people who get into this organization (a) either develop under its conditions, manifesting their best qualities, (b) or are "squeezed out" of the organization by other people whose arete is more fully revealed in this environment, consequently, self-actualization is more effective and significant for this organization.

Thus, as a result of a brief analysis of the three paradigms of organization and the history of their culture development, we found a different understanding of the nature, thinking and roles of the generic and professional managerial skills. Moreover, in some organizational cultures, this difference comes to the opposition.

There appears a need for rethinking the traditional formation of generic and professional skills at the level of undergraduate, graduate, and postgraduate education, on the one hand, in order to maximally eliminate the revealed contradictions between the nature, thinking and roles of generic and professional managerial skills. On the other hand, it is necessary to achieve even greater efficiency from education, as well as greater influence on innovation and innovative approaches, which in turn drive the development of the culture of organizations.

There also appears a need for rethinking the idea of a university as a social institution. First of all, its role in revealing the nature of man, in particular the nature of generic and professional managerial skills, as well as their abilities to effectively express themselves in all existing organizational cultures.

The scientific literature offers various options for rethinking the ideas of a university and the role of a university in the formation of generic and professional skills. For example, A. Sakun and I. Mordous, generally recognizing the difference in views on generic and professional skills, state the priority of the nature of generic skills and, accordingly, the decisive role of academic education. Sakun and Mordous believe that the existing contradiction between generic and professional skills will be removed as a result of solving the problems of sociocultural transformations, social justice, and procedures for identifying a modern individual [8]. Sakun and Mordous analyze the options for solutions proposed at The XXIV World Congress of Philosophy in August 2018. In their opinion, the digitalization of the achievements of the culture of humanities will ensure the identity of generic and professional skills. The digital revolution in education itself will bring academic and professional education closer and eliminate any difference in their impact on the nature of skills. Generic skills will remain basic and defining. However, on the basis of individual, most pronounced generic skills, the professional skills will be formed. This will happen at the last stages of academic education.

Sakun and Mordous argue that the digital revolution will lead to the educational process formalization, which will be seen as an integral part of the similarly formalized process of society development. Formalization and digitalization of the humanities will eliminate the contradictions between the humanities, sciences and practical knowledge. The educational process will become a single one, embedded in the process of the society development and determined by the latter [8]

Możgin W. expresses the opposite point of view [4]. He argues that the idea of universities, formed at the beginning of the $19^{\text {th }}$ century by Wilhelm von Humboldt, is no longer relevant in modern reality. The "university spirit", which determined the nature of generic skills and, accordingly, the whole subsequent life of a young man, is an archaic perception of the idea of a university, which for several decades has had nothing to do with reality. In fact, modern youth has become pragmatic, and their perception of knowledge has become instrumental. Możgin claims that today's youth do not enter universities for comprehensive universal skills, but rather for specific professional skills that will help them make career advancement. Modern youth perceive a university not as an environment that forms a common culture, but as a necessary stage in a professional career. Therefore, the young expect to receive not "worldview" and "eternal" skills at universities, but professional ones, necessary for career growth immediately after graduation [4]

Oleksiyenko A., analyzing the shortcomings of academic reforms in Ukraine, emphasized the fundamental difference between understanding the idea of a university in the postSoviet space and in highly developed countries of the world. Post-totalitarian academic communities are more conservative and impervious to innovation. They keep their traditions and affirm these traditions in their curricula. Accordingly, the skills that are formed in post-Soviet universities and in their organizational culture are significantly different from the skills that are formed in the universities forced to compete in a market economy. Post-Soviet universities are semi-closed academic environments that affirm the value of exclusively generic skills, regardless of their effectiveness in real behavior and management models [9].

Thus, considering the idea of a university as a social institution and its role in revealing the nature of man, in particular the nature of generic and professional skills of a manager, we encountered two opposite points of view. On the one hand, the need to develop Platonic traditions in modern education is asserted [10]. "Traditionalism" and the "traditional approach" in education are established views on the idea of a university, which originates from Humboldt's idea of higher education, which was formulated at the beginning of the $19^{\text {th }}$ century. The basis of this idea is the need for the formation of generic skills, on the basis of which professional skills are subsequently formed, including professional managerial skills. On the other hand, the innovative culture is changing the external environment, which in turn presents new requirements for the education system and forces to rethink the "traditional approach". In particular, as noted by D. Meissner and N. Shmatko, a professional career in the private sector, which has special requirements for employees, as well as in the public sector, the requirements of which are more conservative, have different effects on the formation of the university graduate skills [11].

In a market economy, universities are forced to abandon Platonic traditions, especially in their views on the nature of generic skills and their decisive role in the career of graduates. Knowledge has become a commodity. The university as a social institution was forced to learn to offer this product to consumers. Moreover, demand determined supply. That is, the curricula, as well as the cultural values and norms which go beyond the curricula that were passed on by universities to students, began to be determined not by the history of the university or "Platonic traditions", but by market demand. O. Pavlova claims that higher education institutions of the modern era are the consistent embodiment of the idea of a social institution as an intermediary between spiritual and material production [12]. It means that for modern scholars, the idea of a university as a social institution is an obvious fact in the transi- 
tion from the "university spirit" and the determining nature, thinking and role of generic skills in the life of a graduate to a new understanding. Namely, to understanding the need to act as an "intermediary between spiritual and material production", i. e. to form professional skills along with generic skills.

That is why H. Mintzberg had every right to assert that in the new realities, the history and traditions of the managerial school that he/she graduated from are not important for a future manager. It is important if this school offers high-quality commodity, namely professional skills that allow you to effectively express yourself in a particular organizational culture [1].

In the book Self-organizing Universities, published by Springer in 2019, there was first made an attempt not only to cast doubt on "traditional" university education or to present the university as a "mediator between spiritual and material production" [13]. The authors of this collective monograph tried to rethink the role of universities in training personnel for existing organizational cultures. They presented the idea of a university as a comprehensive model of education, which forms a different nature and thinking of skills in direct proportion to the dominant organizational culture. In fact, the idea of a self-organizing university, presented in the book, correlates with the real demand for professional skills. Thus, a self-organizing university establishes the nature of generic and professional skills in accordance with real demand.

Meissner D. and Shmatko N. argue that an important condition for an innovative culture whose driving force is education is a common understanding of the nature of generic and professional skills [11]. The idea of a self-organizing university is based on the common understanding of the nature of generic and professional skills as well [13].

A logical question arises: "How permissible is a common understanding of the nature of generic and professional skills?" Indeed, as follows from our analysis of the culture of organizations, the understanding of the nature of generic and professional skills in each culture is different.

If we look at Mintzberg's adhocracy, then the fundamental nature of managerial skills or the formation of professional skills is not associated with university education. In market conditions, universities are demand-driven and offer "professional" skills that are generic in nature. It is the substitution of concepts. For example, a student studies as a manager, the university trains his professional managerial skills, but at the same time, as we know, the Weberian bureaucracy, the Mintzberg's adhocracy and self-organizing are three completely different organizational cultures that need completely different managerial thinking. Therefore, a manager graduating from the modern university formally masters professional skills, while in reality they are generic skills.

Moreover, the modern market culture of universities in the pursuit of profit often tries to form "professional" skills in a student whose nature is not prepared or does not correspond to the nature of their chosen professional skills. However, a university as a social institution is not interested in the nature of a student and the orientation of their arete. For a university, tuition, academic performance and formal acquisition of the so-called "professional" skills are important. The final result of the learning process, i.e. the correspondence of the acquired skills to real professional skills turns out to be the problem of a student, not the university. The fact that university graduates are completely unprepared for real management in real organizations is presented by universities as a problem of the graduates themselves, which is associated with an unfair attitude to the learning process. Apparently, this explains the fact that in modern universities, most of the time is devoted to independent preparation of students in academic subjects. In this case, there is always the opportunity to make a graduate appear guilty.

Hence, the conclusion reached by Mintzberg is also logical. Real professional skills manifest themselves only as a result of certain experience in organizations. Managerial think- ing can be formed only by a person who has consciously determined the manager's nature and considers education as an important and necessary stage in their managerial career. In this case, the role of professional skills is crucial and does not depend on the universal skills acquired in the academic environment. A person independently determines the nature of skills and their thinking aimed at the development of this nature, i. e. at the transformation of their nature into professional qualities.

If we consider Weberian bureaucracy, then understanding of the nature of skills, especially the nature of managerial skills, is associated with the formation of generic skills. In the bureaucratic organizational culture, the formation of generic skills is considered as the formation of a person's nature, their way of thinking and way of life. For this reason, the idea of a university as a social institution determines the need to form the nature of generic skills, which in essence is "eternal" and decisive for each university graduate. Subsequently, if necessary, on the basis of generic skills, the level of professional skills will be not only formed but also fixed. In the Weberian bureaucracy, professional skills are acquired as a result of managerial or any other professional experience.

At first glance, we see a similar understanding of the nature of generic skills in the culture of self-managing organizations. In the culture of self-managing organizations, the nature of generic skills is seen as basic and defining. However, in fact, we are talking about a completely new understanding of the nature of generic skills and attitudes towards it in the idea of a university as a social institution. For example, if the Weberian bureaucracy provides for the training of generic managerial skills, and this training is not necessarily related to the nature of a learner, then in self-managing organizations, the idea of a university and academic education is based on revealing the nature of man, their "arete". Managerial skills are not formed, i.e. are not created when affected by the external influence of the educational environment. Skills are not considered as sets of certain principles that lend themselves to formalization, study and formation in the alien nature of man. A priori, the idea of a university provides that these skills are human nature, and the task of a university as a social institution is to reveal and develop them. In fact, the final result of this disclosure is not known. It is not a priority. A new understanding of the nature of the generic managerial skills provides exclusively for the disclosure of the human nature, the discovery of the characteristics of the inner world inherent in man at birth.

As we know, the culture of self-managing organizations does not provide for a hierarchy of management, and often management as such. However, when it comes to the nature of skills that matches the nature of man, we have a completely different final result that cannot be predicted. This is a more perfect stage of individual self-actualization, which does not need accompanying attributes, for example, attributes of power. It is about the new thinking of a manager, about the ability to manage people through the creation of a self-managing organization.

Therefore, a university does not form a set of formalized skills. A university is turning into the environment in which the nature of generic skills is revealed in linear accordance with human nature. As a result, in self-organizing universities, managerial skills are not formed and the managerial profession is not acquired. Self-organizing universities reveal the nature of man. If, as a result of this disclosure, the nature of a manager is revealed, then generic and professional skills are perceived as identical. In this case, a university forms the manager's thinking based on the disclosure of the manager's nature. In the same case, the contradiction between generic and professional skills disappears, because they have common nature and become identical. The new idea of a university as a social institution does not provide for the formation of certain sets of qualities or skills that is customary in the Platonic tradition. Univer- 
sity reveals the nature of a student, as for instance, in the idea of self-organizing universities. Programs of self-organizing universities are able to adapt to the diversity of the nature of students and work with each of them individually [13].

The identical nature of generic and professional skills, resulting from the new idea of a university, determines the society transition to the creation of self-managing organizations. The new thinking of managers allows one not to manage organizations, but to create organizations that formally exist without any management hierarchy, but in fact, they are managed in principle. Managerial thinking goes to a new level of understanding. It is not associated with the achievement of visible attributes of power and manifestations of power. The managerial thinking, identical to manager's nature, reaches the level of creation of the managed organizations. A new understanding of management is approved, as well as a new managerial culture, in which fiction occupies the main place. The peak of managerial culture is the illusion of selfmanagement, because indeed, in this case, the potential of the organization itself becomes much higher than the potentials of Weberian bureaucracy and Mintzberg's adhocracy.

In the new reality, the managerial thinking is aimed at achieving maximum efficiency from the created organization. Therefore, in the case of a decrease in efficiency, the illusion of self-management is replaced by real managerial decisions that lead either to a new increase in the effectiveness of an organization, or to the creation of a new self-managing organization.

Conclusions. Eliopoulos P. investigated the correlation between an oppressor and an oppressed [14]. Researchers of the nature and managerial thinking have been trying to overcome any contrast and even comparison with this correlation for decades. However, it is present and manifests itself to one degree or another in any of the organizational cultures. In this article, we examined the nature, thinking and roles of the generic and professional managerial skills in Weberian bureaucracy, Mintzberg's adhocracy and self-managing organization. We have proved that the identity between the generic and professional skills of a manager is possible only in case of changing the idea of a university. It is possible if you abandon the "Platonic traditions" and accept the idea of self-organizing universities. The new idea of a university as a social institution provides for the disclosure of human nature, and not its formation under certain sets of established truths.

\section{References.}

1. Martela, F. (2019). What makes self-managing organizations novel? Comparing how Weberian bureaucracy, Mintzberg's adhocracy, and self-organizing solve six fundamental problems of organizing. Journal of Organization Design, 8(23). https://doi.org/10.1186/s41469-019-0062-9.

2. Glynn Cochrane (2018). Max Weber's Vision for Bureaucracy. Cham: Palgrave Macmillan. https://doi.org/10.1007/9783-319-62289-7.

3. Lishchuk-Torchynska, T. (2018). Competency Approach in Teaching of the Methodology and Organization of Scientifics Researches for the Future Specialists in Sociology. Sociological studios, 1(12), 32-36. https://doi.org/10.29038/23063971-2018-01-32-36.

4. Możgin, W. (2019). The Condition of a Modern University - Is There a Problem? Future Human Image, 11, 56-65. https://doi.org/10.29202/fhi/11/6.

5. Horban, O., Kravchenko, O., Martych, R., \& Yukhymenko, N. (2019). The regulatory functions of education in behavioral models. Naukovyi Visnyk Natsionalnoho Hirnychoho Universytetu, (3), 152-157. https://doi.org/10.29202/nvngu/2019-3/23. 6. Lee, M., \& Edmondson, A. (2017). Self-managing organizations: Exploring the limits of less-hierarchical organizing. Research in Organizational Behavior, 37, 35-58. https://doi. org/10.1016/j.riob.2017.10.002.

7. Bazaluk, O. (2019). The Revival of the Notion of Arete in Contemporary Philosophy. Schole, 13(1), 198-207. https:// doi.org/10.25205/1995-4328-2019-13-1-198-207.
8. Sakun, A., \& Mordous, I. (2019). Digital Re-Evolution: Learning to be Human at Contemporary Society. Philosophy and Cosmology, 22, 129-136. https://doi.org/10.29202/philcosm $/ 22 / 11$.

9. Oleksiyenko, A. (2019). Why Is Governance Research Important for University Reforms in Ukraine? Ukrainian Policymaker, 4, 27-35. https://doi.org/10.29202/up/4/5.

10. Bazaluk, O. (2019). Plato's Traditions in Modern Educational Theories. Annals of the University of Craiova - Philosophy Series, 43(1/2019), 5-20.

11. Meissner, D., \& Shmatko, N. (2019). Integrating professional and academic knowledge: the link between researchers skills and innovation culture. Journal of Technology Transfer, 44, 1273-1289. https://doi.org/10.1007/s10961-018-9662-8.

12. Pavlova, O. (2018). Classic University as Institutional Form of Human Action. Future Human Image, 9, 92-99. https://doi.org/10.29202/fhi/9/9.

13. Bain, A., \& Zundans-Fraser, L. (2017). The self-organizing University: Designing the higher education organization for quality learning and teaching. Singapore: Springer. https://doi. org/10.1007/978-981-10-4917-0.

14. Eliopoulos, P. (2019). From the Moral Limits of Personal Interest to the Derogation of Individual Identity: Colonialism and Oppression. Ukrainian Policymaker, 4, 4-12. https://doi. org/10.29202/up/4/1.

\section{Універсальні та професійні навички управлінця: зміна природи, мислення та ролей}

\author{
В. С.Білогур ${ }^{1}$, О. П. Кравченко ${ }^{2}$,
}

Т. П. Лішук-Торчинська ${ }^{3}$, Н. Ф. Юхименко

1 - Державний вищий навчальний заклад «Мелітопольський державний педагогічний університет імені Богдана Хмельницького», м. Мелітополь, Україна

2 - Державний вищий навчальний заклад «ПереяславХмельницький державний педагогічний університет імені Григорія Сковороди», м. Переяслав, Україна, e-mail: Natale_ux@ukr.net

3 - Східноєвропейський національний університет імені Лесі Українки, м. Луцьк, Україна

Мета. Дослідження змін природи, мислення й ролей між універсальними та професійними навичками управлінця в різних культурах організації.

Методика. У дослідженні автори використали метод компаративістського аналізу, що дозволив співставити й порівняти існуючі культури організацій. Були використані методи аналізу й синтезу, шо дозволили авторам виокремити та розглянути природу навичок управлінця в кожній з культур організації. Методи індукції та дедукції, а також уявного моделювання дозволили авторам встановити змінення природи навичок, особливості мислення та ролі універсальних і професійних навичок управлінців у різних культурах організації.

Результати. Автори розглянули природу, мислення та ролі універсальних і професійних навичок управлінця у веберівській бюрократії (Weberian bureaucracy), адхократіï Мінцберга (Mintzberg's adhocracy) й самоврядній організації (self-organizing). Автори довели, що для того, щоб домогтися тотожності в розумінні природи універсальних і професійних навичок, необхідно змінити ідею університету як соціального інституту. Як мінімум, прийняти ідею самоорганізуючого університету.

Наукова новизна. Автори довели, що втілення ідеї університету, що самоорганізовується є необхідною умовою створення самоврядних організацій, ефективність самореалізації яких визнана найбільш високою в порівнянні із веберівською бюрократією та адхократією Мінцберга. 
Практична значимість. Отримані результати дослідження розширюють розуміння природи, мислення й ролей між універсальними та професійними навичками управлінців у різних культурах організації. Проведене дослідження підтверджує ефективність університетів, що самоорганізовуються та їх значимість у розкритті природи людини, зокрема природи навичок управлінця.

Ключові слова: навички управліния, культура організації, бюрократія, адхократія, самоврядні організації, управління, універсальні навички, професійні навички, університет, що самоорганізовується

\section{Универсальные и профессиональные навыки управленца: изменение природы, мышления и ролей}

\author{
В. Е. Билогур ${ }^{1}$, Е. П. Кравченко ${ }^{2}$, \\ Т. П. Лищук-Торчинская ${ }^{3}$, Н. Ф. Юхименко
}

1 - Государственное высшее учебное заведение «Мелитопольский государственный педагогический университет имени Богдана Хмельницкого», г. Мелитополь, Украина

2 - Государственное высшее учебное заведение «Переяслав-Хмельницкий государственный педагогический университет имени Григория Сковороды», г. Переяслав, Украина, e-mail: Natale_ux@ukr.net

3 - Восточноевропейский национальный университет имени Леси Украинки, г. Луцк, Украина

Цель. Исследование изменений природы, мышления и ролей между универсальными и профессиональными навыками управленца в различных культурах организации.

Методика. В исследовании авторы использовали метод компаративистского анализа, который позволил сопоставить и сравнить существующие культуры организаций. Были использованы методы анализа и синтеза, ко- торые позволили авторам выделить и рассмотреть природу навыков управленца в каждой из культур организации. Методы индукции и дедукции, а также мысленного моделирования позволили авторам установить изменение природы навыков, особенности мышления и роли универсальных и профессиональных навыков управленцев в различных культурах организации.

Результаты. Авторы рассмотрели природу, мышление и роли универсальных и профессиональных навыков управленца в веберовской бюрократии (Weberian bureaucracy), адхократии Минцберга (Mintzberg's adhocracy) и самоуправляемой организации (self-organizing). Авторы доказали, что для того, чтобы добиться тождественности в понимании природы универсальных и профессиональных навыков, необходимо изменить идею университета как социального института. Как минимум, принять идею самоорганизующихся университетов.

Научная новизна. Авторы доказали, что воплощение идеи самоорганизуюшихся университетов является необходимым условием создания самоуправляемых организаций, эффективность самореализации которых признана наиболее высокой в сравнении с веберовской бюрократией и адхократией Минцберга.

Практическая значимость. Полученные результаты исследования расширяют понимание природы, мышления и ролей между универсальными и профессиональными навыками управленцев в различных культурах организации. Проведенное исследование подтверждает эффективность самоорганизующихся университетов и их значимость в раскрытии природы человека, в частности природы навыков управленца.

Ключевые слова: навыки управлениа, культура организации, бюрократия, адхократия, самоуправляемые организации, управление, универсальные навыки, профессиональные навыки, самоорганизующийся университет

Recommended for publication by V.F. Kaluha, Doctor of Philosophical Sciences. The manuscript was submitted 23.09.19. 